\title{
Doporučení pro duplexní ultrazvukové vyšetření končetinových žil
}

Doporučené postupy vycházejí ze soudobých poznatků lékařské vědy a považují se za postupy lege artis. Jedná se však o doporučení, nikoli předpisy, proto je nutný individuální přístup u každého nemocného. Ošetřující lékař může použít jiný postup, musí však v dokumentaci ráaně zdůvodnit, proč se od doporučeného postupu odchýlil.

\section{Miroslav Vítovec, Václav Pecháček*}

II. interní klinika kardiologie a angiologie, Všeobecná fakultní nemocnice a 1. lékařská fakulta Univerzity Karlovy, Praha, *Soukromá angiologická ambulance, Brno, Česká republika

\section{1. Úvod}

Duplexní ultrazvukové vyšetření (DUZ) je základní neinvazivní metoda $\mathrm{v}$ diagnostice onemocnění žilního systému. Používá se ke zjištění morfologie a funkce hlubokého a povrchového žilního systému na horních a dolních končetinách. Morfologie se vyšetřuje pomocí dvojrozměrného zobrazení a funkce (hemodynamika) pomocí dopplerovských modalit. Vyšetření se provádí v klidu a při různých provokačních manévrech.

Následující text nepodává informace o technických základech sonografie, fyziologii žilního systému ani o patofyziologii sonograficky diagnostikovatelných žilních chorob. Základní znalosti zmíněných oblasti se předpokládají.

\section{Vyšetřování hlubokého žilního systému \\ 2.1. Indikace a technika vyšetření}

Hlavním důvodem vyšetření hlubokého žilního systému je diagnostika tromboembolické nemoci - akutní hluboké žilní trombózy a sledování posttrombotických změn. Při hodnocení posttrombotických změn pomocí DUZ hodnotíme reziduální trombotické hmoty a posuzujeme regurgitaci v hlubokém žilním systému. Méně častým důvodem vyšetření je hodnocení komplikací po punkcích cévního systému (pseudoaneurysmata, arteriovenózní komunikace), ozřejmění jiných patologických stavů v okolí cévní struktury (Bakerova pseudocysta, hematom, zvětšené uzliny), vrozené anomálie a diferenciální diagnostika nejasných stavů suspektních z žilní patologie.

\section{Technika vyšetření}

Vyšetření musí vést ke zjištění abnormit a určení stupně významnosti postižení žilního systému. Abnormity musíme popsat, lokalizovat, zjistit rozsah a dokumentovat. Důležité je nastavení přístroje (stupně šedi, hloubka fokusace, nastavení rychlostí pulsní dopplerovské křivky, rychlostního rozsahu barevného dopplerovského vyšetření).

\section{Poloha nemocného}

Poloha nemocného při vyšetření se mění podle vyšetřované oblasti a typu vyšetření (je rozvedeno dále).

\subsection{Požadavky na vyšetřovací přístroj}

Ultrazvukový přístroj s dvojrozměrným zobrazením (B-mode) s barevným dopplerovským mapováním a spektrálním záznamem pulsního dopplerovského zobrazení (PWD).

Frekvence sondy (rozsah): vhodné k zobrazení normálních struktur cév a patologických hmot v luminu cév. Doporučuje se lineární širokofrekvenční sonda. Frekvence sondy je 5-10 MHz podle vyšetřované oblasti. Se stoupající frekvencí sondy se zlepšuje kvalita anatomického zobrazení v B-mode, ale klesá penetrace.

Dopplerovské modality musejí umožňovat detekci rychlostí v žilním systému. Je třeba mít možnost měnit vzorkovací objem pulsního dopplerovského vyšetření podle velikosti cévy. Vzorkovací objem musí odpovídat průměru žíly. Je nutné mít možnost současně sledovat dvojrozměrné zobrazení (B-mode) a dopplerovské vyšetření.

Adresa: MUDr. Miroslav Vítovec, II. interní klinika kardiologie a angiologie, VFN a 1. LF UK, U nemocnice 2, 12800 Praha 2, Česká republika, e-mail: mvito@If1.cuni.cz 
Většina přístrojů má pro vyšetřování hlubokého žilního systému přednastavení - „preset“. U konkrétního pacienta doporučujeme při vyšetření provádět korekce. Při zobrazení pomocí barevného dopplerovského mapování doporučujeme nastavit rychlostní škálu tak, aby celé lumen bylo vyplněno homogenně; úhel vzorkovacího objemu barevného dopplerovského mapování je třeba upravit tak, aby odpovídal průběhu žíly a směru toku krve. Pro sledování směru a rychlosti toku v žilním systému doporučujeme používat záznam pulsního dopplerovského zobrazení (PWD). Sledujeme změny toku s dýcháním a reakce na augmentační manévry.

Při vyšetření je nutné nastavit správnou fokusaci sondy na vyšetřovanou oblast. Pomoci si můžeme softwarovým vylepšením obrazu - „postprocessing“.

\subsection{Způsob vyšetření hlubokého žilního systému DUZ}

Vždy provádíme dvojrozměrné zobrazení (B-mode) a hodnocení toku krve pomocí barevného dopplerovského mapování a pomocí záznamu pulsního dopplerovského zobrazení.

\subsubsection{Vyšetření hlubokého žilního systému dolních končetin}

\section{Poloha nemocného při vyšetření}

Velikost žilního systému (průměr vyšetřované žíly) se mění s polohou těla. Vzhledem k tomu, že velikost žíly je jednou z diagnostických známek hluboké žilní trombózy, je nutné standardizovat polohu těla nemocného při vyšetření.

Doporučujeme proto vyšetřovat:

> Vleže na zádech pro oblast třísel a stehen - tzv. obrácená Trendelenburgova poloha (horní polovina těla +15 stupňů výše). Většinou lze v této poloze zkontrolovat i distální části lýtkových žil.

>Vleže na břiše pro oblast podkolenní a odstupů lýtkových žil. Doporučujeme lehce elevovat oblast lýtek (+30 stupňů) k odstranění svalového tonu (nohy „postavit na špičky“ nebo podložit).

> Vsedě se svěšenými končetinami (nebo vstoje) pro oblast bércových žil a $\mathrm{k}$ upřesnění nálezu v oblasti podkolení.

> Pro hodnocení chlopenní žilní insuficience doporučujeme polohu vstoje (viz dále).

\section{Postup při vyšetření}

Doporučujeme začít vyšetření příčnými řezy, obvykle od třísel $\mathrm{k}$ periferii, postupovat $\mathrm{v}$ průběhu žíly; vyšetřovat v B-mode a provádět opakované manévry komprese sondou po 1-2 cm. Tento manévr umožňuje zjistit intraluminální patologie - přítomnost trombózy ve vyšetřované žíle. Při zobrazení patologického obsahu lumina žíly je nutné provádět kompresi sondou velmi opatrně. $\mathrm{V}$ místě proximální části trombózy při zobrazení měkkých pohyblivých hmot je komprese sondou riziková. Mohlo by dojít k mechanickému utržení konce trombózy a následné plicní embolii. Při vyšetření je nutné sledovat možnou extravasální pato- logii (např. hematom). Oblast soutoků žil je vhodné zobrazit navíc v podélném směru s využitím barevného dopplerovského mapování a záznamu pulsního dopplerovského vyšetření. Vždy je třeba sledovat spontánní tok a změny toku při augmentačních manévrech. Dopplerovská vyšetření doporučujeme provádět vždy v podélných řezech.

Doporučujeme vyšetřit celý hluboký žilní systém vyšetřované končetiny, sledovat odstupy žil povrchového systému.

\section{Anatomie hlubokého žilního systému dolních končetin} Duplexní sonografií je nutné sledovat hlavní hluboké žíly na dolních končetinách. Vždy sledovat obsah lumina (kompresibilitu a nekompresibilitu) a tok krve v žíle (PWD, barevné mapování).

Z žilních kmenů popisujeme: v. iliaca externa (VIE), která přechází do v. femoralis communis (VFC). V oblasti stehna popisujeme v. femoralis (VF), v. profunda femoralis (VPF). V př́padě potřeby lze zobrazit v. circumflexa femoris medialis a lateralis, nepovažujeme je však za součást standardního vyšetření. Vena femoralis přechází v podkolení (canalis adductorius) do v. poplitea (VP). Při vyšetření $\mathrm{v}$ podkolení popisujeme dále vv. tibiales anteriores (VTA) a posteriores (VTP), vv. fibulares (VFib). V prrípadě potřeby lze popisovat větve v. genus medialis a lateralis, v. gastrocnemica medialis a lateralis, a vv. surales.

V. femoralis a v. poplitea mohou být zdvojeny, stejně tak bércové žíly mohou mít dvojnásobný počet. Tento nález se nepovažuje za patologický stav.

\subsubsection{Vyšetření hlubokého žilního systému horních končetin}

Invazivní vyšetření a léčebné postupy (katetrizace, léčba cestou venózních centrálních katetrů) zvyšují riziko hluboké žilní trombózy horních končetin.

Příčinou hluboké žilní trombózy na horní končetině je u $12 \%$ nemocných centrální katetr a u $23 \%$ povrchových flebitid je důvodem periferní kanyla. K rizikům trombózy na horní končetině se přidávají vrozené trombofilní stavy, získané hyperkoagulační stavy (těhotenství, kontracepce), malignity, operace, traumata, sepse, venózní stáza, anatomické abnormity (kompresivní syndromy horní hrudní apertury). ${ }^{(1)}$

Duplexní vyšetření má na horních končetinách pro diagnostiku hluboké žilní trombózy (HŽT) senzitivitu $78-100 \%$, specificitu $82 \%$ až $100 \%$. $^{(2,3)}$

Falešně negativní výsledky nacházíme u malých, neokluzivních trombů v místech, kde není možné provést kompresi sondou $z$ anatomických důvodů. Špatně zobrazitelné mohou být některé úseky centrálně uložených žil - mediální část v. subclavia, v. brachiocephalica a její soutok s v. cava superior. Obtíže dělají spíše chronické nástěnné změny než akutní trombózy.

Pokud nelze vyšetřovaný žilní úsek komprimovat (např. střední část v. subclavia), doporučujeme sledovat pomocí barevného dopplerovského vyšetření vznik tzv. obtékání kolem trombů anebo se orientovat podle změněné respi- 
rační fazicity toku $\mathrm{v}$ žíle a nálezu kolaterál (nepřímá známka trombózy).

\section{Poloha pro vyšetřování}

Vleže na zádech, s horní končetinou upaženou asi do $60^{\circ}$ stupňů od hrudníku, vyhýbáme se $90^{\circ}-\mathrm{v}$ této poloze je ovlivněn tok sledovaný dopplerovským vyšetřením (mění se normální průtok, amplituda)

\section{Postup při vyšetření + anatomie žilního systému horních končetin}

Doporučujeme začít provádět příčné řezy na vv. brachiales (jsou vždy párové) provázející tepnu. V. basilica a v. cephalica jsou uloženy více na povrchu, typicky ale jen jedna. Bývají větší než vv. brachiales. Centrálně přecházíme na v. axillaris a dále na v. subclavia; venu subclavia zobrazujeme ze supraklavikulární a infraklavikulární projekce (nutnost naklonění sondy).

Centrálně umístěné žíly - mediální část v. subclavia, $\mathrm{v}$. brachiocephalica a soutok $\mathrm{s}$ v. cava superior jsou hůřre zobrazitelné.

Doporučujeme vždy srovnávat nálezy na obou horních končetinách. ${ }^{(3)}$

Při vyšetřování horních končetin doporučujeme vždy popsat i vv. jug. interna a externa. Lze provést i vyšetření hlubokých žil předloktí (radiální a ulnární žíly).

Základním manévrem $\mathrm{k}$ vyloučení patologického obsahu ve vyšetřované žíle je, stejně jako na dolních končetinách, manévr komprese sondou $\mathrm{v}$ př́íných řezech. Tato metoda má i na horních končetinách pro diagnostiku žilní trombózy největší specificitu a senzitivitu. Doporučujeme vždy provést i barevné mapování, především na hůře komprimovatelných úsecích (v. jug. interna, v. subclavia).

\subsection{Diagnostika hluboké žilní trombózy duplexní sonografií}

Senzitivita duplexního ultrazvukového vyšetření pro diagnostiku hluboké žilní trombózy je podle literatury 97\%, specificita $94 \%$. To nás opravňuje ke stanovení diagnózy a k léčbě hluboké žilní trombózy bez dalšího diagnostického testu. Negativní DUZ nás opravňuje k vyloučení hluboké žilní trombózy. ${ }^{(4-6)}$ U negativního DUZ při vysoké suspekci na hlubokou žilní trombózu (HŽT), obzvláště při horší vyšetřitelnosti, doporučujeme opakování vyšetření za 5-7 dní ${ }^{(7)}$ nebo provedení jiného zobrazovacího vyšetření (flebografie). Jiná zobrazovací technika nebo opakování vyšetření s odstupem 5-7 dní jsou nutné i tehdy, pokud nejsme schopni zodpovědně provést vyšetření DUZ pro nemožnost správných projekcí (horší polohovatelnost pacienta), nemožnost provést komprese sondou (pro bolest), nemožnost provést kompletní zobrazení žilního systému (obvazy, sádrové fixace, zranění končetin). ${ }^{(4,8)}$ Opakované vyšetření DUZ doporučujeme při negativním nálezu DUZ $\mathrm{u}$ symptomatického nemocného a $\mathrm{v}$ př́padě, kdy nelze provést flebografii. Opakováním tohoto vyšetření hledáme př́ípadnou progresi trombů. ${ }^{(9)}$
U nemocných s lýtkovou trombózou diagnostikovanou DUZ při vysokém riziku antikoagulační léčby lze doporučit provést opakované vyšetření DUZ za 10-14 dní, a poté znovu zvážit rizika léčby a tromboembolické nemoci. ${ }^{(4,7)}$

Současné ultrazvukové (UZ) prŕstroje jsou schopny zobrazovat lýtkové žíly u velkého procenta pacientů. Dobře proškolený, zkušený vyšetřující je schopen zobrazit lýtkové žíly u 80-98\% pacientů (za pomoci B-mode, barevného dopplerovského vyšetření a PWD). Senzitivita a specificita je v těchto př́padech $90 \% .^{(9,10)}$

\section{Známky hluboké žilní trombózy při vyšetř̌ení duplexní sonografií}

Při vyšetřování doporučujeme vždy provést dvojrozměrné zobrazení (B-mode) a jeho hodnocení, doplněné dopplerovskými modalitami.

Při vyšetření B-mode je třeba zobrazit žilní systém, tj. velikost žil a obsah žil. Na dolních končetinách vždy hodnotit: VI, VFC, junkci VFC a VSM, VPF, VF horní část a oblast Hunterova kanálu, VP, VTP, VTA, VFib a svalové žilní větve.

Při dopplerovském vyšetření je vždy třeba hodnotit barevné dopplerovské mapování a pulsní dopplerovský záznam a zobrazit a hodnotit normální tok v klidu a při manévrech. Kompletnost prováděných manévrů (proximální a distální komprese a dekomprese) záleží na vyšetřitelnosti a přehlednosti hodnocené oblasti.

\section{Za známky DUZ hluboké žilní trombózy se považují:}

A. Velikost žily

Velikost žilního systému se u zdravých dobrovolníků pohybuje v širokém rozmezí. V akutní fázi hluboké žilní trombózy je žíla $\mathrm{v}$ místě trombózy u většiny nemocných rozšířená. Platí to především pro trombózy distálních částí dolní končetiny. $\mathrm{V}$ proximální části končetiny (v oblasti třísla) nemusí ani $\mathrm{u}$ akutní trombózy $\mathrm{k}$ dilataci dojít. $\mathrm{V}$ průběhu ústupu trombózy dochází $\mathrm{k}$ normalizaci velikosti lumen žíly. Z literatury nevyplývá jednoznačný význam měření velikosti ztrombotizované žíly pro diagnostiku HŽT. Problém je především v tom, že velikost žilního systému je velmi variabilní. Při diagnostice HŽT se navíc přidává problém neobturujících trombóz. Hodnocení velikosti žil však považujeme za základní parametr a doporučujeme jej. Dilataci žíly považujeme za známky akutní žilní trombózy. Pro posouzení dilatace žíly doporučujeme srovnat velikost žíly s druhostrannou žílou, s doprovázející tepnou nebo s normami. ${ }^{(11)}$ Za diagnostický se považuje nárůst poměru postižené žíly na dvojnásobek velikosti paralelně jdoucí stejnojmenné tepny. Velikost žilního systému je nutné hodnotit v definovaných místech podle zvyklostí pracoviště. Normální velikost žíly nevylučuje diagnózu hluboké žilní trombózy.

\section{B. Přimé zobrazení patologického obsahu}

Pomocí dvojrozměrného zobrazení (B-mode) zobrazujeme jak normální intraluminální struktury (chlopně), tak i struktury patologické (trombus). Při nálezu patologického obsahu doporučujeme popsat jeho echogenitu, stupeň 
obturace (nástěnné změny, neokludující hmoty, okluze), proximální rozsah trombu a jeho mobilitu (konec pevně přisedlý, volně vlající).

C. Nekompresivnost žily při vyšetření ultrazvukovou sondou Povrchový i hluboký žilní systém je pomocí ultrazvukové sondy volně stlačitelný. Komprese je obtížnější v distální části Hunterova kanálu a v mediální ćásti v. subclavia. Kompresibilita je omezena také při obezitě a otocích vyšetřované končetiny. Žílu vyplněnou patologickou strukturou nelze stlačit. Síla komprese, které je zapotřebí k dosažení kolapsu vyšetřované žíly, může být u jednotlivých nemocných různá. Jako měřítko dostatečného tlaku doporučujeme sledovat kompresi žíly, provázející tepny. Pokud již začínáme komprimovat tepnu a žíla se nekomprimuje, je vyplněna patologickými hmotami. Nutno rozlišit ztíženou (ale zachovanou) kompresibilitu žil u stavů spojených se žilní hypertenzí od omezení kompresibility pro patologický obsah v luminu žíly.

D. Defekt v náplni při barevném dopplerovském mapování Pokud se nacházejí v luminu žíly obturující patologické hmoty, při barevném dopplerovském mapování nevidíme žádný tok. Při změnách, zabírajících jen část průsvitu, vidíme tzv. fenomén obtékání. Pro lepší zobrazení toku doporučujeme provádět barevné dopplerovské mapování při kompresních manévrech (distální komprese, při které dochází $\mathrm{k}$ augmentaci toku ve vyšetřované žíle).

\section{E. Změny žilního toku hodnoceného spektrálním záznamem pulsního dopplerovského zobrazení (PWD)}

Doporučujeme vždy vyšetřit a zobrazit kolísání rychlosti toku krve v souvislosti s dýcháním (tzv. dechovou modulaci spontánní nebo při forsírované respiraci nebo při Valsalvově manévru) a změny rychlosti toku při manuální augmentaci. Změněný tok je pak známkou patologie v žilním systému. Jde o neprrímou známku postižení proximálních či distálních žilních etáží. Absence kolísání toku s respirací může být důsledkem trombózy proximální části žilního řečiště, ale důvodem může být i žilní hypertenze nebo útlak proximálněji uloženého úseku žíly (nádorem, dělohou v těhotenství).

\section{Ostatní známky}

Dilatace žil při Valsalvově manévru jako známka průchodnosti pánevní etáže, nález žilních kolaterál jako známka trombózy staršího data.

Duplexní sonografii k detekci hluboké žilní trombózy doporučujeme provést i v př́padě diferenciální diagnostiky plicní embolie. $^{(12)}$

\subsection{Odhad stáŕi trombotických hmot}

Duplexní sonografie není metodou, která by dokázala vždy spolehlivě odlišit staré posttrombotické změny od čerstvé trombózy. Práce, které se snažily zjistit stáří trombózy podle stupně echogenity trombů, skončily nezdarem. Vzhledem $\mathrm{k}$ tomu, že tato otázka je z klinického hlediska důležitá, musí sonografista přispět svým popisem $\mathrm{k}$ rozlišení staré trombózy od čerstvé. Podle popisu trombotických hmot jsou jasné krajní póly. Za čerstvou trombózu považujeme trombotické hmoty v dilatované žíle: hmoty jsou měkké, částečně komprimovatelné, mají vlající konec, jsou homogenně echogenní, mohou být i hypoechogenní až anechogenní. Za starou trombózu považujeme persistentní echogenní až hyperechogenní až hyperechogenní hmoty v žíle normální velikosti, většinou neobturující.

\subsection{Hodnocení chlopenní insuficience $\checkmark$ hlubokém žilním systému}

Posttrombotický syndrom se často objevuje až několik let po proběhlé trombóze žilního systému. ${ }^{(13)}$ Podle některých autorů je však zjevný už do dvou let po akutní trombóze. ${ }^{(6,14,15)}$

Příčinou posttrombotického syndromu je žilní hypertenze ze žilní obstrukce, insuficience žilních chlopní, nebo kombinace obojího. Žilní insuficience je považována za nejvýznamnější přičinu posttrombotického syndromu. Žilní insuficienci hodnotíme podle doby refluxu v žilním systému. Reflux hodnotíme pomocí vyšetření PWD při různých manévrech. Zjistíme tak tzv. regurgitační čas. Regurgitační čas je nejčastěji udávaným parametrem pro vyjádření žilní insuficience. Nicméně pro hodnocení žilní insuficience lze použít při vyšetření DUZ i další parametry. Kromě regurgitačního času lze hodnotit velikost žíly, maximální rychlost regurgitace, střední rychlost regurgitace; můžeme vypočítat regurgitační objem.

V literatuře není shoda v hodnocení stupně velikosti žilní insuficience měřené časem regurgitace. Po rozboru literatury doporučujeme považovat regurgitační čas nad $0,5 \mathrm{~s} \mathrm{za}$ detekci žilní insuficience - „refluxu”, za možné známky inkompetence žil a nemocného je nutné dále vyšetřit. ${ }^{(16,17)}$ Hodnotu regurgitačního času bez dalšího určení způsobu měření nedoporučujeme použít ke kvantifikaci tíže žilní insuficience. Regurgitační čas spolehlivě detekuje žilní insuficienci - reflux; jeho konkrétní hodnota je ale špatným prediktorem vývoje posttrombotického syndromu. ${ }^{(18)}$

Pro hodnocení stupně žilní regurgitace (vyjádření tíže onemocnění) doporučujeme vzít v úvahu způsob, jakým jsme regurgitaci zjistili i jiné parametry získané při vyšetření DUZ.

\section{Hodnocení regurgitačního času}

Reflux, tj. regurgitační čas, doporučujeme měřit na hlubokém systému vstoje, $s$ vahou přenesenou na nehodnocenou končetinu. Reflux hodnotíme pulsním dopplerovským vyšetřením (PWD) po augmentačních manévrech. $\mathrm{V}$ praxi doporučujeme provedení manuální komprese a sledování změny toku při uvolnění - manévr distální dekomprese (při klidném stoji nemocného). Za přesnější, ale pracnější, považujeme hodnocení regurgitace vyvolané prudkým uvolněním manžety tonometru, která byla nafouknuta na definovaný tlak. Manžetu tonometru doporučujeme nafouknout na $80 \mathrm{~mm} \mathrm{Hg}$ při hodnocení regurgitace v oblasti trrísla a stehna a na $100 \mathrm{~mm} \mathrm{Hg}$ při hodnocení v oblasti lýtka. $\mathrm{V}$ základních publikacích se $\mathrm{k}$ tomuto účelu použí- 
vají speciální přístroje. Lze si pomoci vytažením hadice $\mathrm{z}$ tonometru. Hodnotíme čas regurgitace při rychlé deflaci, která má být kratší než $1 \mathrm{~s}$; $^{(17)}$ vše hodnotíme v klidném stoji nemocného.

\section{Poloha při vyšetření}

Poloha vleže na zádech

Regurgitační čas (reflux) lze vyšetřovat vleže na zádech (obrácená Trendelenburgova poloha). Regurgitaci v této poloze lze hodnotit v oblasti třísla (femorální confluens) a proximální části v. femoralis - při Valsalvově manévru. Podle literatury lze vleže hodnotit i distální části v. femoralis. Doporučuje se pak proximální manuální komprese. My tento způsob nedoporučujeme, vleže připouštíme jen možnost hodnocení regurgitace v hlubokém žilním systému pro oblast třísla při Valsalvově manévru. ${ }^{(15,19)}$

\section{Poloha vstoje}

Za nejpřesnější pro hodnocení regurgitačního času považujeme vyšetření vstoje za použití manévru dekomprese. Manévr dekomprese vstoje nejlépe odráží patofyziologickou situaci př̀i žilní insuficienci.

\section{Regurgitační časy}

Pro zvýšení specificity vyšetření podle způsobu provedení manévru doporučujeme následující hodnocení patologických regurgitačních časů:

> Při vyšetření vstoje (manévr dekomprese tonometrem nebo manuální dekomprese): v oblasti VF, VP, čas delší než $1 \mathrm{~s}$, ostatní oblasti nad $0,5 \mathrm{~s}$.

> Při vyšetř̌ení vleže: Valsalvưv manévr v oblasti třísla - čas nad 1,0 s, v distální části stehna a dále distálně nedoporučujeme reflux hodnotit Valsalvovým manévrem. S výhradami lze připustit při hodnocení distálních částí vena femoralis manévr proximální komprese. Za známky žilní insuficience pak považujeme časy nad $0,5 \mathrm{~s} .{ }^{(11,20)}$

\section{Hodnocení maximální rychlosti regurgitace}

Jako další parametr hodnocení významnosti regurgitace lze doporučit hodnocení maximální rychlosti regurgitace. Maximální rychlost regurgitace, hodnocená při augmentačních manévrech nad $30 \mathrm{~cm} / \mathrm{s}$, je spojena s významnou inkompetencí chlopní. ${ }^{18-20)}$ Konkrétní hodnota závisí na způsobu vyvolání regurgitace (typy augmentačního manévru) a bude jistě v budoucnu upravena.

\subsection{Popis nálezu duplexního ultrazvukového vyšetření}

Popis diagnózy hluboké žilní trombózy by měl obsahovat: rozsah trombózy, stupeň obturace žilního systému, rozměry žíly v místě trombózy, popis charakteru trombotických hmot a odhad stáří trombotických hmot.

Při hodnocení známek chlopenní insuficience třeba definovat místo zjištěné regurgitace, použitý manévr, odhad stupně regurgitace.

\section{Vyšetřování povrchového žilního systému a perforátorů}

\subsection{Indikace}

a) Chronická žilní onemocnění (C 0-6)

> Diferenciální diagnostika při diskrepanci symptomatologie a klinického obrazu;

> Diferenciální diagnostika klinických známek chronické žilní insuficience (hlavně otoků);

> V souvislosti s invazivním řešením varikózní choroby;

b) Tromboflebitida

c) Cévní malformace

d) Vyšetření zdravých žil (odběr graftu, našití AV píštěle)

\subsection{Teoretický úvod}

\subsubsection{Anatomická terminologie}

\section{Úvod}

Povrchový žilní systém se vyznačuje velkou variabilitou, která se odráží v nejednotnosti názvosloví. Ta může být překážkou kvalitního přenosu informací mezi vyšetřujícím a př́ijemcem sonografického nálezu. Doporučuje se používat terminologii dohodnutou mezinárodními odbornými společnostmi. ${ }^{(21,22)} \mathrm{Z}$ ní vychází i níže uvedené sdělení.

\section{Žilní systémy a kompartmenty}

>Žilní systémy - hluboký, povrchový a perforátorový.

> Kompartmenty - hluboký (pod svalovou fascií) a povrchový (nad fascií). Z povrchového kompartmentu lze vydělit kompartment safénový, který je jeho součástí. Je ohraničen jednak svalovou fascií a jednak safénovou fascií.

> Žíly můžeme dělit na hluboké (v hlubokém kompartmentu) a povrchové (v povrchovém kompartmentu).

Poznámka: S přechodem na trojvrstevný model se nabízí následující terminologie: žíly subfasciální (v hlubokém kompartmentu), žíly interfasciální (v safénovém kompartmentu) a žíly epifasciální (v povrchovém kompartmentu mimo safénový kompartment). Pojem epifasciální tedy může mít užší či širší význam (a možná to je důvod, proč se v aktuálních mezinárodních konsensech nepoužívá).

\section{Safény}

Za safénu lze označit jen tu žílu, která je uložena v safénovém kompartmentu.

\section{Ostatní povrchové žíly \\ Klasifikované}

Akcesorní safény, kraniální extenze malé safény, circumflexní žíly stehna, intersafénové žíly bérce a žíly laterálního komplexu.

Bezejmenné

\section{Perforátory}

Doporučuje se používat popisné pojmy, ukazující na lokalizaci perforátoru, nikoli názvy odvozené od jmen významných osobností (př́iklad: paratibiální, medicínsky gastroknemický apod). 


\section{Eponyma}

Používání eponym se obecně nedoporučuje. Zejména v mezinárodním měřítku lze považovat za anatomicky jednoznačně daná a současně široce srozumitelná jen tato označení: Giacominniho vena, Cockettovy perforátory a Santoriniho plexus.

\section{Obecné pojmy}

Viz tabulka 1.

\section{Zkratky}

Nejsou stanovena žádná oficiální doporučení. V níže uvedeném textu budou zkratky týkající se názvů žil odvozovány $\mathrm{z}$ platné latinské terminologie. $\mathrm{V}$ naprosté většině odpovídají zvyklostem zažitým v našem prostředí. V ojedinělých případech mohou sice působit atypicky, ale zmíněná konstrukce má nesporné výhody: vylučuje různé česko-latinsko-anglické kombinace, a ulehčuje tak dešifrování zkratek.

\subsubsection{Reflux}

Valnou část doby při vyšetření povrchového žilního systému zabírá zjištování přítomnosti či nepřítomnosti patologického refluxu, jakožto projevu valvulární insuficience. Pochopení a akceptování jeho zákonitostí je pro správnou sonografickou diagnostiku nezbytné.

\section{Definice}

Žilní reflux je retrográdní tok v inkompetentní žíle, která spojuje dva segmenty končetiny s rozdílnými tlaky. Trvá déle, než je fyziologický uzavírací čas chlopní v dané lokalitě.

Poznámka: Krátký zpětný tok před uzavřením chlopně je přítomen i za fyziologických okolností a jako reflux se neoznačuje.

\section{Aplikace na primární varixy}

V klidu je tlak v hlubokém i povrchovém žilním systému stejný a žádný reflux se neobjevuje. Po zapojení svalově-žilní pumpy dochází $\mathrm{z}$ hlediska tlaku $\mathrm{v}$ hlubokých žilách $\mathrm{k}$ rozdělení končetiny na dva segmenty. V proximálním segmentu (vena poplitea včetně a výše) je tlak vyšší než v distálním úseku. Pokud tyto segmenty spojuje na povrchu suficientní vena, reflux se neobjevuje, pokud je spojuje insuficientní vena, reflux je v ní př́tomen. ${ }^{(23)}$

\section{Atributy}

Každý reflux má začátek (zdroj), cestu (inkompetentní žílou popr. žílami) a konec (ústí, tj. místo návratu refluktující krve zpět do hlubokého systému).

\subsection{Prístroj}

\section{Výbava}

Přístroj s CFM (kontinuální dopplerovské vyšetření) a PWD (pulsní dopplerovké vyšetření), který umožňuje rozlišit nejméně $2 \mathrm{~mm}$ žílu a zachytit i pomalé toky (kolem $6 \mathrm{~cm} / \mathrm{s}$ ).

Lineární multifrekvenční sonda s rozsahem zahrnujícím pásmo 7,5-10 MHz (lépe 5-12 MHz), umožňující vyšetření od bezprostředně podkožní oblasti do hloubky $5-7 \mathrm{~cm}$.

\section{Nastavení}

B-mode

Př́jmové zesílení (zisk, gain), dynamický rozsah (dynamic range) a případně mapu šedé škály nastavit tak, aby lumen normálně průchodné žíly bylo anechogenní (černé). Fokusační zony zacílit do míst zájmu v konkrétní fázi vyšetření.

\section{Dopplerovo vyšetření}

Rychlostní spektrum (scale) při vyšetření v PWD i CFM modu nastavit tak, aby se daly zachytit i pomalé toky kolem $5-10 \mathrm{~cm} / \mathrm{s}$, filtry (wall filter) stáhnout tak, aby pomalé toky nebyly arteficiálně eliminovány. Př́ijmové zesílení (gain) nastavit tak, aby byla zajištěna maximální senzitivita systému (spíše gain mírně přidat, protože př̀ vyšetření refluxu nebudou vadit - na rozdíl od vyšetření tepenných stenóz přesahy barvy mimo žílu).

\section{Ukládání záznamů}

Konvence: $\mathrm{v}$ longitudinálním řezu by měl být proximální konec žíly na snímku vlevo, transverzální řezy by měly odpovídat pohledu jakoby odspodu končetiny. Barva: ortográdní venózní tok modře, retrográdní červeně. ${ }^{(24)}$

\subsection{Venózní hemodynamické mapování \\ 3.4.1. Úvod}

V níže uvedeném textu bude popsána metoda venózního hemodynamického mapování (venous hemodynamic

Tabulka 1 Obecné pojmy

\begin{tabular}{lll}
\hline Pojem & Definice & Sonografická poznámka \\
\hline Ageneze & Kompletní absence & $\begin{array}{l}\text { Nelze odlišit, používá se termín aplazie, pokud struktura není } \\
\text { ultrazvukovým vyšetřením nedetekovatelná }\end{array}$ \\
\hline Aplazie & Nevyvinutí (struktura je v „embryonální velikosti“) & Prakticky: průměr $<50 \%$ normálu \\
\hline Dypoplazie & Inkompletní vývoj & \\
\hline Aneurysma & $\begin{array}{l}\text { Lokalizovaná dilatace venózního segmentu, průměr zvětšen } \\
0>50 \% \text { proti nedilatované žíle }\end{array}$ & \\
\hline
\end{tabular}


mapping - VHM), která pokrývá celou indikační šíři vyšetřování povrchových žil. ${ }^{(24,25)}$ Protože kompletní mapování patří mezi časově náročnější výkony, je běžné, že rozsah vyšetření bývá modifikován podle konkretní indikace a podle praktického přínosu v dané klinické situaci. Některé speciální indikace budou rozvedeny $\mathrm{v}$ dalších kapitolách.

\subsubsection{Cíl vyšetření}

Odhalení prrítomnosti a určení rozsahu morfologické a funkční patologie. Nejčastěji jde o zjištění cesty venózního refluxu.

\subsubsection{Obecná část}

\section{Prostředí}

> Místnost: přiměřená teplota (chlad může vést ke konstrikci žil a snížení senzitivity vyšetření refluxu).

> Pomůcky, které zlepšují komfort vyšetřujícího (stolička) a pacienta (opěrka) pro vyšetření vstoje.

\section{Poloha pacienta}

Doporučená je vertikální poloha (vyšetření celých DK vstoje, nebo stehna ve stoje a lýtka vsedě), a to kvůli hodnocení chlopenní funkce. ${ }^{(20,24,26-29)}$ Důležitá je relaxace vyšetřované končetiny: lehké pokrčení a odlehčení, případně lehká zevní rotace, váha na druhé noze.

Horizontální poloha neskýtá proti vertikální poloze žádné relevantní výhody a při testování chlopenní funkce si vynucuje použití méně fyziologických manévrů, je tedy méně vhodná. ${ }^{(30,31)}$ Pro vyšetření saféno-femorální junkce a okolí lze alternativně použít 15-30stupňovou reverzní Trendelenburgovu (RT) pozici. Poloha $\mathrm{v}$ polosedě či 30stupňová RT připadá v úvahu jako nouzová při sklonu k vasovagálním obtížím vstoje.

\section{Vyšetření morfologie}

Obraz normální žily

Stěny větších žil jsou tenké, hladké a stř̌edně echogenní, stěny menších žil se sonograficky nezobrazují. V lumen (větších žil) je možno zachytit pohybující se cípy chlopní, někdy bývá přítomen spontánní echokontrast daný agregáty erytrocytů, jinak je lumen anechogenní. Spontánní echokontrast dočasně mizí po manévrech, které urychlují tok krve. Žíla je plně kompresibilní.

\section{Postup vyšetření}

Průběh žíly sledujeme v transverzálním řezu, posunováním sondy proximo-distálním směrem, resp. podle průběhu žíly. Vyšetření v longitudinálním řezu je třeba použít v místech specifického zájmu (aneurysmata, junkce, perforátory, sporné nálezy apod).

\section{Obsah vyšetření}

Odchylky v počtu: a) do minus: nepřítomnost (aplazie, po chirurgickém výkonu), b) do plus: duplikace, resp. obecně multiplikace.
Morfologické abnormality:

a) Velikost: hypoplazie/varikózní dilatace (změření průsvitu v př́padech, kdy má údaj praktický dopad)/aneurysmatická dilatace.

b) Struktura: atypie u hemangiomů apod.

c) Intraluminální obsah: trombotický, posttrombotický, po endovaskulární léčbě.

\section{Popis průběhu}

Pokud jde o významnou varikózní žílu, jejíž průběh jednoznačně nevyplývá z názvu.

\section{Vyšetření funkce (reflux)}

Fáze vyšetření

Zobrazení vyšetřované žíly - provokační manévr - detekce toku - zhodnocení

\section{Zobrazení}

Pro rutinní vyšetření většiny žil se hodí šikmý řez a detekce refluxu pomocí CFM. V oblasti junkcí je vhodné doplnit zobrazení v podélném řezu. Největší senzitivitu a specificitu má vyšetření pomocí PWD v podélném řezu, které je však časově i technicky náročnější. Je nutné $\mathrm{k}$ němu přistoupit při vyšetření perforátorů a ve všech sporných situacích kdekoli jinde.

Poznámka k projekci: Šikmý řez vychází z transverzálního řezu, po detekci žíly se sonda mírně klopí směrem $\mathrm{k}$ žíle tak, aby insonace neprobíhala $\mathrm{v}$ rovině kolmé $\mathrm{k}$ její dlouhé ose, ale pod úhlem kolem $60^{\circ}$ a méně. Čistý transverzální řez by vedl ke snížení senzitivity dopplerovského vyšetření.

\section{Provokační manévry}

Pro testování refluxu je třeba $\mathrm{v}$ žíle vytvořit tlakový gradient, a to pomocí provokačního manévru. ${ }^{(17)}$ Univerzálně použitelný je manévr „uvolnění distální komprese“, který se provádí tak, že distálně od insonovaného úseku vyšetřující krátce stlačí končetinu pacienta a rychle stisk povolí. Př́itomnost refluxu se detekuje při uvolnění komprese a $\mathrm{v}$ době bezprostředně následující. Při rutinním vyšetření je dostačující manuální komprese. ${ }^{(32)}$ Pokud je třeba zvýšit senzitivitu nebo získat zcela reprodukovatelné výsledky (výzkum), je nutné použít prrístrojovou kompresi pomocí nafukovacích manžet. Manévr je nejúčinnější při vyšetření pacienta ve vertikální poloze.

\section{Hodnocení}

Hlavním sledovaným parametrem je doba trvání zpětného toku, přičemž za patologii (a tedy prŕtomnost refluxu) se považuje čas delší než 0,5 s. ${ }^{(24)}$ Ačkoli jde o kvantitativně vyjádřitelnou hodnotu (s), je nutno se na tento parametr dívat jako na kvalitativní (přítomnost či nepřítomnost patologie). Délka trvání refluxu totiž nekoreluje $s$ tíží choroby. ${ }^{(33)}$

Další měřitelné parametry (rychlostní a objemové) jeví určitou korelaci s tíží choroby, ale v současné době je nelze považovat za nutnou součást vyšetření. 
Poznámka: V oblasti saféno-femorální junkce a proximálního stehna lze použít i Valsalvův manévr (lépe v 15-30 RT). ${ }^{(34)}$ Nebylo prokázáno, že by měl proti manévru distální komprese zásadní výhody, poukazuje se na jeho limitace, zvláště pokud je prováděn jako nestandardizovaný. Spíše než za plnohodnotnou alternativu ho lze považovat za komplementární a používat selektivně. Ve specifických situacích připadá v úvahu i manévr aktivní dorsiflexe v kotníku nebo izometrické kontrakce svalů lýtka (problémy s kompresí, perforátory).

\section{Souhrn}

Při vyšetření systematicky mapujeme hlavní žilní kmeny a dále všechny žíly, které se jeví relevantní podle klinického vyšetření, nebo u nichž jsme sonograficky zachytili odchylku od normy. Začínáme obvykle v oblasti třísla a pokračujeme distálním směrem. Vyhodnocujeme paralelně morfologické abnormality a prítomnost refluxu. Syntézou těchto informací získáváme přehled o tzv. vzorci postižení, tzn. určujeme, kde se reflux objevuje (zdroj), jakými žílami se šírí (cesta), a kde se vrací do hlubokého žilního systému (ústí, kanalizace). U každé jednotlivé žíly postižené chlopenní insuficiencí lze určit její proximální a distální bod insuficience, tj. kde se v ní reflux objevuje a kde mizí. Tyto body se nemusejí krýt s koncem a počátkem žíly $\mathrm{v}$ anatomickém slova smyslu.

\subsubsection{Protokoly pro jednotlivé oblasti a struktury}

Následující text obsahuje anatomické a sonografické údaje, jejichž akceptace by mohla př̀ispět k určité jednotnosti při hodnocení konkrétních lokalit. Vychází z doporučení mezinárodních odborných společností. ${ }^{(21,22,24,25)}$ Nebudou opakována triviální anatomická fakta, detailnější popis techniky UZ vyšetření bude uveden jen $\mathrm{v}$ př́ípadě, že se $\mathrm{v}$ něčem liší od informací uvedených $\mathrm{v}$ obecné části (viz výše).

\section{Saféno-femorální junkce}

(junctio saphenofemoralis, JSF)

\section{Anatomické poznámky}

Anatomická definice: místo vtoku VSM do VFC.

Anatomicko-klinický koncept: oblast ohraničená proximálně suprasafénovou chlopní ve VFC (resp. VIE) a distálně preterminální chlopní ve VSM a infrasafénovou chlopní ve VFC. Součástí junkce jsou také centripetální části ostatních přítoků (do jejich terminální chlopně) a venózní sít přilehlé lymfatické uzliny (či uzlin). Důležitou strukturou uvnitř popsané oblasti je terminální chlopeň před vyústěním VSM. Přítoky obvykle ústí do VSM mezi terminální a preterminální chlopní a dělí se na proximální a distální.

\section{Technika vyšetření}

Identifikace základních struktur v příčném řezu $\mathrm{v}$ oblasti tříselné rýhy a distálně od ní. Zhodnocení chlopenní funkce VSM preferenčně $\mathrm{v}$ podélném řezu (tortuózní průběh žíly či anomálie mohou vyžadovat jiné zobrazení), zhodnocení chlopenní funkce ostatních distálních přítoků $\mathrm{v}$ příčném řezu a při jejich insuficienci došetření.

\section{Obsah vyšetření}

Posouzení chlopenní funkce, $v$ případě insuficience určení, do kterého $\mathrm{z}$ př́toků reflux směřuje. Při nálezu nestandardního uspořádání junkce nutný detailní popis. Důležité je postihnout zejména případy, kdy insuficientní žíla ústí do hlubokého systému samostatně, a nikoli prostřednictvím terminálního úseku VSM.

Poznámka: $\mathrm{V}$ rámci detailnějších studií je možno rozlišovat i postižení jednotlivých chlopní v JSF.

\section{Velká saféna}

(vena saphena magna, VSM)

\section{Anatomické poznámky}

Normální průměr je 4-4,5 mm a méně. Vena je uložena v safénovém kompartmentu, kryta fasciemi. Relativně častá je její absence či hypoplazie v segmentu distální části stehna, $\mathrm{v}$ úrovni kolena nebo v proximálním bérci (v $28 \%$ př́padů).

\section{Echoanatomie}

Identifikace VSM

a) Tř́slo: spojení s VFC.

b) Stehno: safénový kompartment má tvar oka, kde „spodní víčko“ tvoří echogenní linie svalové fascie, „horní víčko“ echogenní linie safénové fascie a „duhovku“ samotná anechogenní saféna. Útvar je dobře diagnostikovatelný $\mathrm{v}$ proximálním stehně, kde je safénová fascie integrální. $\mathrm{V}$ distální části stehna a v úrovni kolena může být hưře zobrazitelný.

c) Proximální bérec: safénový kompartment leží v trojúhelníku ohraničeném tibií, $\mathrm{m}$. gastrocnemius medialis a z vrchní strany echogenní fascií.

d) Distální bérec: VSM běží při mediální hraně tibie, fascie $\mathrm{k}$ ní těsně přiléhají.

Hypoplazie: lumen $<2 \mathrm{~mm}$ (podle některých autorů $\leq 1 \mathrm{~mm}$ ). Aplazie: v safénovém kompartmentu není žíla detekovatelná (při použití standardního ultrazvukového př́ístroje).

\section{Saféno-popliteální junkce}

(junctio saphenopoplitea, JSP)

\section{Anatomické poznámky}

Hlavním rysem junkce je její variabilta, která se týká jednak terminálního úseku VSP, a jednak její kraniální extenze.

Varianty terminálního úseku VSP (od zanoření do hloubky po spojení s hlubokým žilním systémem jsou:

a) do plusu: duplikovaná, resp. (multiplikovaná) junkce,

b) do minusu: terminální úsek je hypoplastický nebo chybí (VSP pokračuje proximálně, aniž by v oblasti popliteální jamky komunikovala s hlubokým systémem),

c) prrítomen normální terminální úsek: spojení s hlubokou žilou je pak samostatné (izolované) nebo společně s gastroknemickými žilami.

Umístění junkce: nejčastěji $2-4 \mathrm{~cm}$ proximálně od popliteální rýhy (zhruba v 60 \%). 
Technika vyšetření

V transverzálním řezu identifikace základních struktur (VP gastroknemické žíly, VSP a její kraniální extenze), následně vyšetření chlopenní funkce podle zásad uvedených v obecné části (zobrazení volit podle konkrétní anatomické situace).

Obsah vyšetření

Posouzení chlopenní funkce, $v$ prrípadě insuficience popis uspořádání JSP, určení úrovně soutoku VSP a VP ( $\mathrm{v} \mathrm{cm} \mathrm{od}$ úrovně podkolenní rýhy).

\section{Malá saféna}

(vena saphena parva, VSP)

\section{Anatomické poznámky}

Normální průměr je do $3 \mathrm{~mm}$. Vena leží v safénovém kompartmentu (kryta fasciemi).

\section{Echoanatomie}

Identifikace VSP

a) Proximální lýtko: VSP jde v rýze mezi hlavami gastroknemických svalů a safénový kompartment má triangulární tvar (dvě strany tvořeny svalovou fascií a povrch překlenuje safénová fascie).

b) Distální lýtko: safénový kompartment má semilunární tvar.

\section{Kraniální extenze malé safény}

(extensio cranialis venae saphenae parvae, ECVSP, př́padně jen EC, podle kontextu)

\section{Anatomické poznámky}

$\mathrm{V}$ podkolení se terminální část VSP zanořuje do hloubky směrem $\mathrm{k}$ hlubokým žílám. Ještě před zanořením může z VSP odstupovat žíla, která směřuje proximálně na dorsálním stehně. Jde o kraniální extenzi VSP. Z embryologického hlediska lze rozlišovat dva typy. Axiální (méně častý) - jde v hlubší vrstvě podél ischiadického nervu, postaxiální (běžný) jde více po povrchu a v dalším průběhu se může napojovat jak na hluboké, tak na povrchové žíly stehna.

Poznámka: Varianta, při které se postaxiální kraniální extenze VSP napojuje v dorzální části stehně na v. circumflexa femoris posterior, směřující do VSM, se nazývá Giacominniho vena. ${ }^{(35)}$

\section{Echoanatomie}

Postaxiální kraniální extenze je uložena $\mathrm{v}$ interfasciáním prostoru trojúhelníkovitého tvaru, který připomíná safénový kompartment. Směřuje do žlábku, ohraničeného $\mathrm{z}$ mediální strany $\mathrm{m}$. semimembranosus a následně m. semitendinosus a $\mathrm{z}$ laterální strany $\mathrm{m}$. biceps femoris. $\mathrm{Na}$ povrchu je žlábek kryt fascií.

\section{Přídatné safény}

> (vena saphena magna accessoria anterior, posterior, superficialis - VSMAA, VSMAP, VSMAS)

> (vena saphena parva accessoria superficialis - VSPAS)
Poznámka: V běžné praxi lze očekávat užití zkratky pravděpodobně jen $\mathrm{v}$ př́ípadě VSMAA.

\section{Anatomické poznámky}

Přídatné safény jsou vertikální venózní segmenty různé délky, jdoucí paralelně s VSM (resp. VSP), dominantně mimo safénový kompartment, a to na stehně, na bérci či v celé délce.

VSMAA: končí pravidelně v JSF, u $14 \%$ varikózních pacientů má klinický význam, drénuje často uzliny v oblasti junkce.

VSMAP: vyústění v JSF je nekonstantní, často distálně od preterminální chlopně. Bércový segment odpovídá „posterior arch vein“ - Leonardově žíle.

\section{Echoanatomie}

VSMAA: terminální (různě dlouhý) úsek může jít v safénovém kompartmentu. Distálněji na stehně jde žíla v hlubší vrstvě podkoží, někdy je patrný její vlastní kompartment, ohraničený z povrchu echogenním fasciálním pruhem. Vůči VSM jde anteriorně a laterálně, v blízkém vztahu k poloze hlubokého cévního svazku („alignment sign“), zatímco VSM jde od hlubokého svazku dorsálně.

VSMAP: terminální část může procházet safénovým kompartmentem, ve zbylém průběhu jde posteriorně od VSM, v proximálním stehně je sporadicky patrný vlastní kompartment.

VSMAS: jde povrchně od VSM.

VSPAS: jde povrchně od VSP.

\section{Další povrchové žíly}

Anatomické poznámky

Zbylé povrchové žíly můžeme rozdělit na klasifikované (= něčím charakteristické, a tudíž pojmenované) a na ostatní (bezejmenné). Vzhledem $\mathrm{k}$ velké variabilitě této úrovně žilního systému se však doporučuje používat spíše popisné pojmy (kudy žíla jde).

Klasifikované žíly: šikmé žíly stehna (v. circumflexa femoris anterior, posterior) a bérce (venae intersaphenae) a žíly laterálního komplexu (laterální venózní systém). Šikmé žíly jdou oblastmi, které vyplývají z názvu a variabilně se napojují na vertikální kmeny (safény a jejich př́idatné větve, kraniální extenzi VSP, př́padně laterální komplex). Laterální venózní systém je rozprostřen v oblasti laterálního stehna a bérce. Je pozůstatkem embryonální vena marginalis lateralis.

\section{Patofyziologické poznámky}

Pojem mimokmenové varixy označuje varikozity se zdrojem patologického refluxu mimo junkce a hlavní kmeny. Reflux přichází bud' z perforátorů, nebo z pánve.

\section{Perforátory}

Posouzení funkce perforátorů je problematická součást VHM, a to $\mathrm{z}$ následujících důvodů:

1. Není plná shoda na definici insuficientního perforátoru;

2. Není zlatý standard, se kterým by bylo možno jednotlivé metody a parametry porovnávat;

3. Není definitivně a $\mathrm{v}$ širokém rozsahu stanovena role perforátorů $\mathrm{v}$ patofyziologii chronické žilní insuficience 
a potažmo klinická významnost insuficientního perforátoru, jasné jsou jen dílčí klinické situace. Názory na tuto problematiku jsou ve vývoji a diagnostická doporučení uvedená níže se snaží reflektovat nejaktuálnější trendy.

\section{Anatomické poznámky}

Perforátory dolních končetin se dělí podle mezinárodních doporučení do šesti skupin (hýždové, stehenní, kolenní, bércové, kotníkové a nožní).(22)

\section{Patofyziologické poznámky}

Při invazivním měření bylo zjištěno, že $\mathrm{v}$ době svalové kontrakce lýtka směřuje tlakový gradient $\mathrm{z}$ hloubky k povrchu, v době svalové relaxace je tomu naopak. V souladu s tímto tvrzením lze najít práce, uvádějící sonografický záchyt „patologického" toku v bercových perforátorech až u 20 \% zdravých osob. Jiní autoři uvádějí, že bidirekcionální tok je častější u pacientů s varixy než u zdravých osob. $Z$ výše uvedeného plyne, že pouhý záchyt toku směrem k povrchu - bez ohledu na další skutečnosti - nelze brát s dostatečnou jistotou jako jediný průkaz insuficience perforátoru.

\section{Echoanatomie}

Identifikace: je nutno detekovat průchod svalovou fascií.

\section{Technika vyšetření}

Morfologie

$\mathrm{V}$ příčném řezu sledujeme jak povrchovou, tak hlubokou žílu (postupně či najednou, podle anatomických poměrů) a hledáme žilní struktury, které je spojují. Většinou jsou tortuózní, a nelze je tedy zobrazit $\mathrm{v}$ jednom řezu celé. Spojení povrchového a hlubokého systému je bud' přímé, nebo nepřímé (přes svalové žilní větve).

\section{Funkce}

Vyšetření se provádí ve vertikální poloze, manévrem „uvolnění distální komprese“. K základní orientaci je vhodné použít CFM, exaktní změření refluxu je ale nutno provést pomocí PWD. Za patologický je považován tok trvající přes $0,5 \mathrm{~s},{ }^{(28)}$ (jdoucí směrem $\mathrm{z}$ hlubokého do povrchového systému, který je přítomný po uvolnění komprese, tedy ve svalové diastole). ${ }^{(36)}$

Poznámka: V literatuře se objevují i dobře dokumentované údaje o hranici $0,35 \mathrm{~s}^{(20)}$

Než budou $\mathrm{k}$ dispozici nové vědecké údaje, resp. širší shoda, lze doporučit otestovat perforátor i proximální kompresí a fyziologickými manévry (izotonická či izometrická kontrakce svalů lýtka). Indikací tohoto postupu jsou zejména perforátory:

a) jejichž význam ve vzorci postižení není zcela jasný,

b) nacházející se v distálních oblastech cesty refluxu.

Lze také odhadovat množství krve proudící perforátorem jedním a druhým směrem a v úvahu brát jen „čistý reflux“ směrem $\mathrm{k}$ povrchu.
Četnost insuficientních perforátorů stoupá s jejich průměrem: nad $3 \mathrm{~mm}$ jsou insuficientní často a nad $4 \mathrm{~mm}$ téměř vždy. Přesto se nepřímé určení insuficience perforátoru (pouze podle změření průměru) nepovažuje za korektní postup. $^{(37)}$

\section{Obsah vyšetření}

Lokální hledisko: detekce insuficientního perforátoru, změření průměru v místě průchodu fascií, určení polohy (včetně údaje o vzdálenosti od podložky či přesně definovaných částí končetiny).

Celkové hledisko: klinická důležitost nálezu a potažmo úvaha o nutnosti invazivního řešení se neodvíjí jen od prostého průkazu chlopenní insuficience $\mathrm{v}$ perforátoru, ale také od jeho pozice ve „vzorci“ postižení. Insuficience perforátoru je téměř vždy spojena $s$ refluxem $\mathrm{v}$ povrchovém nebo hlubokém systému (nebo v obou) a s ohledem na charakter postižení tohoto „okoli“" lze perforátory třídit s praktickými důsledky. ${ }^{(38)}$ Např́klad u primárních varixů je nutno rozlišovat perforátory, které jsou zdrojem refluxu (exit, non-terminal perforators), a které jsou ústím refluxu (re-entry, terminal perforators). Druhé jmenované perforátory navíc procházejí s progresí žilní insuficience několika fázemi.

\section{Recidivy varixů}

Vyšetření recidivujících varixů se metodicky neliší od vyšetření dosud nedotčené varikózní choroby. Jediným nálezem, který lze detekovat pouze u recidiv, je neovaskularizace. Jedná se o mnohočetné varikozity malého průměru a tortuózního průběhu, které vedou reflux $\mathrm{z}$ místa, kde byla provedena operace (téměř výlučně jde o oblasti junkcí).

\section{Technika vyšetření}

Oblast prohlížíme v transverzálním řezu. Není výjimkou, že neovaskularizační žilky nejsou vidět v B-modu, ale jsou detekovatelné až v podobě patologického refluxu, zobrazeného pomocí CFM.

\subsubsection{Nález}

Standardním zpo̊sobem záznamu vyšetření je slovní popis. Není stanovena oficiální konvence, nicméně lze doporučit vést popis $\mathrm{v}$ retrográdním směru, tedy ve směru propagace venózního refluxu. Osvědčilo se (zvláště u složitějších nálezů) zaznamenat výsledek vyšetření v grafické podobě (schéma).

\subsubsection{Délka platnosti VHM}

Je prokázáno, že pokud je klinický nález stabilní a neproběhla interkurentní žilní trombotická příhoda, lze výsledek VHM považovat za relevantní po dobu šesti měsíců. ${ }^{(39)}$

\subsubsection{Indikace VHM před invazivním řešením varikózní choroby}

Rozhodování o vhodnosti invazivního řešení (zda lze očekávat po výkonu zlepšení) 
Kompletní duplexní ultrazvukové vyšetření včetně VHM je indikováno vždy, pokud $\mathrm{z}$ anamnézy, klinického obrazu či ultrazvukového nálezu na hlubokém systému vzniknou nejasnosti týkající se etiologie či patofyziologie žilního postižení a pacient invazivní řešení neodmítá.

\section{Rozhodování o taktice výkonu \\ Klasická operace}

Lze předpokládat, že každý pacient bude mít určitý užitek z provedení VHM. Míra prospěchu se u jednotlivých pacientů bude lišit podle toho, nakolik výsledek VHM změní strategii výkonu proti situaci, kdy se operuje podle klinického odhadu. Největší propěch lze očekávat u těchto skupin pacientů: s recidivujícími varixy, suspekcí na postižení VSP, s chronickou žilní insuficiencí C4 a výše, s klinickým nálezem neumožňujícím provést solidní odhad (obezita, atypické varixy apod.).

Pokud jsou kapacity dostačující, je VHM indikován $\mathrm{u}$ všech pacientů chystajících se $\mathrm{k}$ výkonu, $\mathrm{v}$ opačném případě je žádoucí, aby kapacity byly využity přednostně k vyšetření skupin s předpokladem vysokého prospěchu (viz výše).

Endovenózní metody (fyzikální i chemické)

Před použitím endovenózních metod je VHM nezbytný.

\subsection{Modifikace VHM při vyšetřování $\checkmark$ dalších indikacích}

\subsubsection{Flebitida dolních a horních končetin}

\section{Tromboflebitida}

K diagnóze lze použit kritéria platná u hluboké trombózy (intraluminální obsah, nekompresibilita). Vyšetření je možno provést vleže a omezit se jen na hodnocení morfologických abnormalit. Kromě prostého diagnostikování prrítomnosti tromboflebitidy se zjištuje její rozsah a př́padně vývoj v čase.

\section{Mondorova flebitida postihující povrchové žíly hrudníku a břicha}

Obliterace lumen v různé míře, někdy i zesílení stěny, nebývá dilatace žíly. Postižené žíly jsou obvykle menšího průměru, vyšetření probíhá často na hraně rozlišovací schopnosti prŕístroje.

\subsubsection{Venózní malformace v oblasti povrchového kompartmentu}

Při vyšetření v B-modu jsou patognomické abnormality v počtu, tvaru, velikosti či uspořádání. Venózní charakter malformace podporuje nález kompresibility. Důležité je určení rozsahu a charakteru léze (ohraničená či infiltrativní). Pomocí dopplerovských modů se jednak potvrzuje cévní charakter vyšetřovaného útvaru, a jednak se posuzuje průtok. Rozlišují se malformace vysokoprůtokové (AV malformace, AV fistule) a nízkoprůtokové (venózní, lymfatické). U komplexnějších lézí vždy následuje došetření dalšími metodami (magnetická rezonance, angiografie apod.).

\subsubsection{Vyšetřování žil jako potenciálních bypassů}

Z povrchových žil vyšetřujeme VSM (popř. VSP), v případě nouze v. basilica a v. cephalica. Kritéria diskvalifikující žílu pro bypass jsou: obliterace, postflebitické změny, přítomnost četných odstupujících větví, varikózní charakter a malý průměr. Kritérium průměru se může lišit podle typu plánovaného výkonu a naléhavosti indikace; mohou být i rozdílné zvyklosti na různých pracovištích. Z praktického hlediska lze doporučit zpracování výsledku vyšetření do podoby náčrtu s uvedením průměru žíly $\mathrm{v}$ různých etážích, přičemž o provedení (či rozsahu) odběru si rozhodne chirurg. Obecně lze říci, že zcela nevhodné jsou žíly s průměrem pod 2,5 mm, žíly kolem $3 \mathrm{~mm}$ mají potenciál dilatovat se po umístění do arteriálního řečiště ke $4 \mathrm{~mm}$ a $\mathrm{v}$ případě nouze mohou být použitelné. ${ }^{(40)}$ Vhodné jsou kmeny $3,5-4,5 \mathrm{~mm},{ }^{(41)} \mathrm{lze}$ použít i lehce dilatované žíly (kolem $5 \mathrm{~mm}$ ), s přibývajícím průměru se ale stává limitujícím faktorem jejich varikózní charakter.

\section{Literatura}

1. Luciani $A$, Clement $O$, Halimi $P$, et al. Catheter-related upper extremity deep venous thrombosis in cancer patients: a prospective study based on Doppler US. Radiology 2001;220:655-60.

2. Prandoni P, Polistena P, Bernardi E, et al. Upper-extremity deep vein thrombosis. Risk factors, diagnosis, and complications. Arch Intern Med 1997;157:57-62.

3. Patel MC, Berman LH, Moss HA, McPherson SJ. Subclavian and internal jugular veins at Doppler US: abnormal cardiac pulsatility and respiratory phasicity as a predictor of complete central occlusion. Radiology 1999; 211:579-83

4. Kearon C, Julian JA, Newman TE, Ginsberg JS. Noninvasive diagnosis of deep venous thrombosis. McMaster Diagnostic Imaging Practice Guidelines Initiative. Ann Intern Med 1998;128:663-77.

5. Andrews EJ Jr, Fleischer AC. Sonography for deep venous thrombosis: current and future applications. Ultrasound Q 2005;21:213-25.

6. Vítovec M, Roztočil K, Frídl P. Thrombus regresion after six month standard therapy versus extended anticoagulation for one year. A duplex scanning imaging study. Minerva Cardiologica 2000;48:202.

7. Birdwell BG, Raskob GE, Whitsett TL, et al. The clinical validity of normal compression ultrasonography in outpatients suspected of having deep venous thrombosis. Ann Intern Med 1998;128:1-7.

8. Zierler BK. Ultrasonography and diagnosis of venous thromboembolism. Circulation 2004;109 (12 Suppl 1):I9-I14.

9. Bradley MJ, Spencer PA, Alexander L, Milner GR. Colour flow mapping in the diagnosis of the calf deep vein thrombosis. Clin Radiol 1993;47:399-402.

10. Rose SC, Zwiebel WJ, Nelson BD, et al. Symptomatic lower extremity deep venous thrombosis: accuracy, limitations, and role of color duplex flow imaging in diagnosis. Radiology 1990;175:639-44.

11. Vítovec $M$, Frídl, $P$, Roztočil $K$. Vyšetřování žilního systému dolních končetin pomocí duplexního ultrazvuku. Cor Vasa 1995;37:240-7.

12. Wells PS, Ginsberg JS, Anderson DR, et al. Utility of ultrasound imaging of the lower extremities in the diagnostic approach in patients with suspected pulmonary embolism. J Intern Med 2001;250:262-4.

13. Prandoni $P$, Lensing AW, Cogo $A$, et al. The long-term clinical course of acute deep venous thrombosis. Ann Intern Med 1996;125:1-7.

14. Bernardi E, Prandoni P. The post-thrombotic syndrome. Curr Opin Pulm Med 2000;6:335-42.

15. Saarinen J, Kallio $T$, Lehto $M$, Hiltunen $S$, Sisto $T$. The occurrence of the post-thrombotic changes after an acute deep venous thrombosis. A prospective two-year follow-up study. J Cardiovasc Surg (Torino) 2000; 41:441-6.

16. Yamaki T, Nozaki M, Sakurai H, Takeuchi M, Soejima K, Kono T. High peak reflux velocity in the proximal deep veins is a strong predictor of advanced post-thrombotic sequelae. J Thromb Haemost 2007;5:305-12. 
17. van Bemmelen PS, Bedford G, Beach K, Strandness DE. Quantitative segmental evaluation of venous valvular reflux with duplex ultrasound scanning. J Vasc Surg 1989;10:425-31.

18. Yamaki T, Nozaki M, Sasaki K. Quantitative assessment of superficial venous insufficiency using duplex ultrasound and air plethysmography. Dermatol Surg 2000;26:644-8.

19. Danielsson G, Eklof B, Grandinetti A, Lurie F, Kistner RL. Deep axial reflux, an important contributor to skin changes or ulcer in chronic venous disease. J Vasc Surg 2003;38:1336-41.

20. Labropoulos N, Tiongson J, Pryor L, et al. Definition of venous reflux in lower-extremity veins. J Vasc Surg 2003;38:793-8.

21. Caggiati A, Bergan JJ, Gloviczki P, Eklof B, Allegra C, Partsch H. Nomenclature of the veins of the lower limb: extensions, refinements, and clinical application. J Vasc Surg 2005;41:719-24.

22. Caggiati A, Bergan JJ, Gloviczki P, Jantet G, Wendell-Smith CP, Partsch H. Nomenclature of the veins of the lower limbs: an international interdisciplinary consensus statement. J Vasc Surg 2002;36:416-22.

23. Recek C. The venous reflux. Angiology 2004;55:541-8.

24. Coleridge-Smith P, Labropoulos N, Partsch H, Myers K, Nicolaides A, Cavezzi A. Duplex ultrasound investigation of the veins in chronic venous disease of the lower limbs-UIP consensus document. Part I. Basic principles. Eur J Vasc Endovasc Surg 2006;31:83-92.

25. Cavezzi A, Labropoulos N, Partsch H, et al. Duplex ultrasound investigation of the veins in chronic venous disease of the lower limbs-UIP consensus document. Part II. Anatomy. Eur J Vasc Endovasc Surg 2006;31:288-99.

26. Eberhardt RT, Raffetto JD. Chronic venous insufficiency. Circulation 2005;111:2398-409.

27. Min RJ, Khilnani NM, Golia P. Duplex ultrasound evaluation of lower extremity venous insufficiency. J Vasc Interv Radiol 2003;14:1233-41.

28. Nicolaides AN. Investigation of chronic venous insufficiency: A consensus statement (France, March 5-9, 1997). Circulation 2000;102:E126-E163.

29. Meissner MH, Moneta G, Burnand K, et al. The hemodynamics and diagnosis of venous disease. J Vasc Surg 2007;46 Suppl S:4S-24S.

30. Markel A, Meissner MH, Manzo RA, Bergelin RO, Strandness DE Jr. A comparison of the cuff deflation method with Valsalva's maneuver and limb compression in detecting venous valvular reflux. Arch Surg 1994;129:701-5.
31. Araki CT, Back TL, Padberg FT Jr, Thompson PN, Duran WN, Hobson RW 2nd. Refinements in the ultrasonic detection of popliteal vein reflux. JVasc Surg 1993;18:742-8.

32. Yamaki T, Nozaki M, Sakurai H, Takeuchi M, Soejima K, Kono T. Comparison of manual compression release with distal pneumatic cuff maneuver in the ultrasonic evaluation of superficial venous insufficiency. Eur J Vasc Endovasc Surg 2006;32:462-7.

33. Neglen P, Egger JF, 3rd, Olivier J, Raju S. Hemodynamic and clinical impact of ultrasound-derived venous reflux parameters. J Vasc Surg 2004;40:303-10.

34. Masuda EM, Kistner RL, Eklof B. Prospective study of duplex scanning for venous reflux: comparison of Valsalva and pneumatic cuff techniques in the reverse Trendelenburg and standing positions. J Vasc Surg 1994;20:711-20.

35. Georgiev M, Myers KA, Belcaro G. The thigh extension of the lesser saphenous vein: from Giacomini's observations to ultrasound scan imaging. JVasc Surg 2003;37:558-63.

36. Delis KT. Perforator vein incompetence in chronic venous disease: a multivariate regression analysis model. J Vasc Surg 2004;40:626-33.

37. Labropoulos N, Mansour MA, Kang SS, Gloviczki P, Baker WH. New insights into perforator vein incompetence. Eur J Vasc Endovasc Surg 1999;18:228-34.

38. van Neer PA, Veraart JC, Neumann HA. Venae perforantes: a clinical review. Dermatol Surg 2003;29:931-42; discussion 942.

39. Labropoulos N, Leon L, Kwon S, et al. Study of the venous reflux progression. J Vasc Surg 2005;41:291-5.

40. Cruz CP, Eidt JF, Brown AT, Moursi M. Correlation between preoperative and postoperative duplex vein measurements of the greater saphenous vein used for infrainguinal arterial reconstruction. Vasc Endovascular Surg 2004;38:57-62.

41. Levi N, Schroeder T. Preoperative ultrasound mapping of the saphenous vein: prognostic value on early post operative results, a prospective study. Osaka City Med J 1997;43:77-80.

Poděkování: Autoři děkují za pomoc při zpracování doporučení oponentu MUDr. Simonu Jirátovi, a dále doc. MUDr. Deboře Karetové, CSc., MUDr. Ireně Muchové, MUDr. Jiř́mu Spáčilovi, CSc., a doc. MUDr. Janu Malíkovi, CSc., za připomínky. 